\title{
Dioxin exposure and non-malignant health effects: a mortality study
}

Angela C Pesatori, Carlo Zocchetti, Stefano Guercilena, Dario Consonni, Davide Turrini, Pier Alberto Bertazzi

\begin{abstract}
Objective-To investigate, in a population heavily exposed to $2,3,7,8$-tetrachlorodibenzo-p-dioxin (TCDD), the possible unusual occurrence of diseases other than cancer.

Methods-Five year extension of the fol-
\end{abstract} low up of the cohort involved in the Seveso accident. Soil measurements identified three exposure zones: (A) highest contamination, (B) substantial, and (R) low but higher than background contamination. Blood TCDD measurements, although limited in number, confirmed zone exposure ranking. The 15 year mortality in the exposed cohort was compared with that of a large population in the surrounding non-contaminated territory. Relative risks (RRs) and $95 \%$ confidence intervals (95\% CIs) were estimated with Poisson regression techniques.

Results-The already noted increased occurrence of cardiovascular deaths was confirmed, in particular in zone $A$, among males for chronic ischaemic heart disease (five deaths, RR 3.0, 95\% CI 1.2 to 7.3 ), and among females for hypertensive disease (three deaths, RR 3.6, 95\% CI 1.2 to 11.4) and chronic rheumatic heart disease. Novel findings were the increase of chronic obstructive pulmonary disease, most notably among males in zone $A$ (four deaths, RR 3.7, 95\% CI 1.4 to 9.9) and females in zone $B$ (seven deaths, RR 2.4, 95\% CI 1.1 to 5.1); and from diabetes, which was significantly increased in females in zone $B$ (13 deaths, RR 1.9, 95\% CI 1.1 to 3.2$)$. In zone $R$, chronic ischaemic heart disease (males and females), hypertension (females), and diabetes (females) showed less pronounced, although significant excesses.

Conclusions-As well as high TCDD exposure, the accident caused a severe burden of strain in the population. Both these factors might have contributed to the noted increased risks (in particular, circulatory and respiratory). The cardiovascular and immune toxicity of TCDD, as well as its complex interaction with the endocrine system, might be relevant to the explanations of these findings. These results, although not conclusive, concur with previous data in suggesting cardiopulmonary and endocrine effects in humans highly exposed to TCDD.

(Occup Environ Med 1998;55:126-131)

Keywords: dioxins; Seveso; mortality
The public health concern surrounding polychlorinated dibenzo-para-dioxins (PCDDs) is justified by the extreme toxicity of some of these compounds, by their ubiquity in food, and their persistence in the environment. ${ }^{12}$ The most toxic congener, 2,3,7,8-tetrachlorodibenzo-p-dioxin (TCDD), showed a wide range of severe effects in animal experiments, including immunotoxicity, developmental and reproductive toxicity, teratogenicity, and carcinogenicity. ${ }^{3}$ Effects in humans have been extensively studied, but the picture is not fully consistent and is probably incomplete. As well as cancer, ${ }^{45}$ effects on skin, ${ }^{6-14}$ liver, ${ }^{10}{ }^{15-21}$ thyroid, ${ }^{22}{ }^{23}$ immune system, ${ }^{24}$ lipid ${ }^{162125}$ and glucose metabolism, ${ }^{2126}$ and the circulatory system have been reported. ${ }^{27}{ }^{28}$ The possible association of reproductive and developmental effects with TCDD exposure is still controversial. ${ }^{29}$

One of the populations most heavily exposed to TCDD is that involved in the Seveso, Italy accident that occurred in 1976 in a chemical plant where 2,4,5 trichlorophenol was manufactured. The accident originated with an uncontrolled exothermic reaction in one of the production kettles, causing a sudden surge in temperature and pressure that blew a safety device. The reactor content, a fluid mixture containing some $2900 \mathrm{~kg}$ of organic matter, as well as sodium hydroxide, ethylene glycol, sodium trichlorophenate, trichlorophenol, and a substantial amount of $2,3,7,8,-$ TCDD, was released into the air through an exhaust pipe and deposited as far as $6 \mathrm{~km}$ south east of the factory.

The most heavily contaminated area (zone A) covered some 87 hectares, and mean concentrations of $2,3,7,8,-$ TCDD between $15.5 \mu \mathrm{g} / \mathrm{m}^{2}$ and $580.4 \mu \mathrm{g} / \mathrm{m}^{2}$ were recovered from soil samples. ${ }^{30}$ A further contamination zone with concentrations not exceeding $50 \mu \mathrm{g} /$ $\mathrm{m}^{2}$ covered 270 hectares (zone B). A third area of 1430 hectares extended to where detectable levels of TCDD (nominally, $<0.75 \mu \mathrm{g} / \mathrm{m}^{2}$ ) were measured. This zone $\mathrm{R}$ had a patchy, low contamination generally below $5 \mu \mathrm{g} / \mathrm{m}^{2}$. After a few weeks, most of the residents in zone A (over 700 people) were ordered to leave the area. In zone B, people remained in their houses but strict regulations were issued to avoid consumption of home grown products (vegetables and animals). Limiting regulations were also issued for residents of zone $\mathrm{R}$.

In the early period after the accident, the most obvious effect was the extremely high occurrence of chloracne (a skin lesion known to be associated with exposure to chlorinated 
polyaromatic hydrocarbons) $)^{31}$ that affected $19.6 \%$ of children aged $3-14$ years living in zone A. Several surveys on early and mid-term health outcomes possibly associated with exposure to TCDD-for example, neurological, immunological, and hepatic impairment, cytogenetic effects, birth defects, and abortion rates-were conducted under the supervision of an international steering committee. $^{32} 33$ Most of these investigations yielded inconclusive results, due in part to flaws in study planning - for example, the lack of appropriate reference groups-and especially to the complex crisis situation that undermined the implementation of a sound epidemiological design and jeopardised essential study steps-for example, standardisation of methods and procedures and subjects' compliance. ${ }^{32}{ }^{34}$ In 1984 the steering committee concluded that "it is obvious that no clearcut adverse health effects attributable to TCDD, besides chloracne, have been observed", but indicated the need for further studies embracing the time span of appearance of possible late effects. ${ }^{35}$

Long term investigations on cancer incidence and mortality were designed and implemented. In the first decade after the accident, the incidence study showed an increase for cancer of the hepatobiliary tract, for lymphatic and haemopoietic neoplasms, and for soft tissue sarcoma. ${ }^{36}$ For this study the time has been extended. The mortality study also examined non-cancer causes, ${ }^{37}$ and we report here updated results for a 15 year period, July 1976 to June 1991.

\section{Materials and methods}

The accident area is part of a specific region north of Milan (named Brianza), and it included part of the territory of two health districts encompassing 11 municipalities. The study population comprised all people of any age and both sexes residing in one of those municipalities at the date of the accident. The information about town and street address at the date of the accident was used to attribute subjects to the exposure category corresponding to one of the contamination zones, or to the surrounding non-contaminated territory the population of which (nearly sixfold larger than the exposed population, table 1) was adopted as a source of reference data. The 1981 census data for the Province of Milan were examined to compare the characteristics of the contaminated municipalities with the reference area for occupational, social, and educational background. ${ }^{38}$ No differences were found in educational level achieved, economic sector of employment, and position at work, family size, and housing (number of rooms and available services). Also, the population of all municipalities within the two joint health districts shared the same hospitals, health services, and family physicians.

Exposure classification was based on environmental contamination data-namely, results of TCDD measurements in soil. Within five weeks of the accident, the contaminated area was subdivided into zones $\mathrm{A}, \mathrm{B}$, and $\mathrm{R}$ in descending amount of exposure. The total
Table 1 Mortality, 1976-91, from non-malignant causes in the Seveso population (study population)

\begin{tabular}{lrrrr}
\hline Zones & $\begin{array}{l}\text { Subjects } \\
(n)\end{array}$ & $\begin{array}{l}\text { Not traced } \\
(n(\%))\end{array}$ & $\begin{array}{l}\text { Males } \\
\text { (person-years) }\end{array}$ & $\begin{array}{l}\text { Females } \\
(\text { person-years) }\end{array}$ \\
\hline A & 805 & $7(0.9)$ & 5541 & 5975 \\
B & 5943 & $53(0.9)$ & 42219 & 41391 \\
R & 38625 & $361(0.9)$ & 265408 & 271483 \\
Reference & 232747 & $2066(0.9)$ & 1536724 & 1622631 \\
\hline
\end{tabular}

amount of TCDD released is considered to be in the order of several kilograms. ${ }^{33}$ The actual level of exposure in each zone can be evaluated in comparison with the blood values of TCDD measured in subsamples of the study population. In blood samples taken in 1976-7, the following blood median concentrations were measured among the most exposed subjects older than 13 years: zone A 177 subjects, 443 pg/g blood lipids; zone B 54 subjects, 87 pg/g blood lipids; zone R 17 subjects, $15 \mathrm{pg} / \mathrm{g}$ blood lipids. ${ }^{4}$ In 1992-3, additional samples were collected in randomly selected subjects older than 20 years participating in an ongoing molecular epidemiology study. The TCDD blood concentrations (geometric mean), nearly 20 years after the accident, were: zone A seven subjects, $53.2 \mathrm{pg} / \mathrm{g}$ blood lipids; zone B 51 subjects, $11.0 \mathrm{pg} / \mathrm{g}$ blood lipids; reference area 55 subjects, $4.9 \mathrm{pg} / \mathrm{g}$ blood lipids. ${ }^{39}$

Each person in the population was followed up from the date of the accident to the end of 1991. For those who left their initial residence, the search started from the last known address, from the information recorded on municipal vital statistics registries, which are available throughout the whole country, until the person was located and the vital status ascertained. Exposed and control subjects were traced concurrently and with the same methods. All tracing procedures were implemented without knowledge of the subjects' exposure status. This assured, among other things, a nondifferential accuracy in the ascertainment and coding of cause of death.

The stability of the mortalities derived from the control population was evaluated through a comparison with the rates of the population of the entire region of Lombardy (nearly 9000000 inhabitants). ${ }^{37}$ Minor discrepancies emerged. The temporal trend of mortality in the area was also examined and, for one cause of cancer, mortality was higher in the TCDD contaminated zones than in the reference area, even before the accident. ${ }^{40}$ Comparison of rates was performed with standard Poisson regression techniques, ${ }^{41}$ controlling for age and calendar period. Relative risks (RRs) and 95\% confidence intervals (95\% CIs) were estimated, as well as the number of expected deaths for each cause of death. Separate analyses were performed by zone, sex and duration of follow up, which in this particular analysis, corresponded with the number of years elapsed since initial exposure (latency).

\section{Results}

Table 1 shows the results of the follow up. Ascertainment of vital status was successful for over $99 \%$ of the whole cohort, and the success rate did not vary across zones. 
Table 2 Mortality, 1976-91, from non-malignant causes in the Seveso population (males, all ages)

\begin{tabular}{|c|c|c|c|c|c|c|c|c|c|}
\hline \multirow{2}{*}{$\begin{array}{l}\text { Cause of death } \\
\text { ICD-9 }\end{array}$} & \multicolumn{3}{|l|}{ Zone A } & \multicolumn{3}{|l|}{ Zone B } & \multicolumn{3}{|l|}{ Zone $R$} \\
\hline & $\begin{array}{l}\text { Observed } \\
\text { deaths }\end{array}$ & $\begin{array}{l}\text { Relative } \\
\text { risk }\end{array}$ & $95 \% C I$ & $\begin{array}{l}\text { Observed } \\
\text { deaths }\end{array}$ & $\begin{array}{l}\text { Relative } \\
\text { risk }\end{array}$ & $95 \% C I$ & $\begin{array}{l}\text { Observed } \\
\text { deaths }\end{array}$ & $\begin{array}{l}\text { Relative } \\
\text { risk }\end{array}$ & $95 \% C I$ \\
\hline All causes (1-999) & 39 & 1.0 & 0.8 to 1.4 & 255 & 0.9 & 0.8 to 1.1 & 1898 & 1.0 & 1.0 to 1.1 \\
\hline Infectious, parasitic disease (1-139) & $(0.2)$ & & & $(1.2)$ & & & 8 & 1.0 & 0.5 to 2.1 \\
\hline Diabetes $(250)$ & $(0.6)$ & & & 6 & 1.3 & 0.6 to 2.9 & 37 & 1.1 & 0.8 to 1.6 \\
\hline All circulatory disease (390-459) & 21 & 1.6 & 1.1 to 2.5 & 90 & 0.9 & 0.7 to 1.1 & 719 & 1.1 & 1.0 to 1.2 \\
\hline Hypertension $(400-405)$ & 1 & 2.3 & 0.3 to 16.5 & $(3.7)$ & & & 32 & 1.3 & 0.9 to 1.9 \\
\hline Ischaemic heart disease $(410-414)$ & 9 & 1.5 & 0.8 to 2.9 & 36 & 0.8 & 0.6 to 1.2 & 316 & 1.1 & 0.9 to 1.2 \\
\hline Myocardial infarction (410) & 4 & 0.9 & 0.3 to 2.5 & 17 & 0.6 & 0.4 to 0.9 & 188 & 0.9 & 0.8 to 1.1 \\
\hline Chronic ischaemic heart disease $(412,414)$ & 5 & 3.0 & 1.2 to 7.3 & 18 & 1.3 & 0.8 to 2.1 & 126 & 1.4 & 1.1 to 1.7 \\
\hline Cerebrovascular disease $(430-438)$ & 5 & 1.5 & 0.6 to 3.7 & 30 & 1.2 & 0.8 to 1.7 & 190 & 1.1 & 0.9 to 1.3 \\
\hline Respiratory disease $(460-519)$ & 5 & 2.4 & 1.0 to 5.7 & 13 & 0.7 & 0.4 to 1.3 & 122 & 1.0 & 0.9 to 1.3 \\
\hline \multicolumn{10}{|l|}{ Chronic obstructive pulmonary disease } \\
\hline$(490-493)$ & 4 & 3.7 & 1.4 to 9.9 & 9 & 1.0 & 0.5 to 1.9 & 67 & 1.1 & 0.8 to 1.4 \\
\hline Digestive disease (520-579) & 2 & 0.6 & 0.2 to 2.6 & 15 & 0.7 & 0.4 to 1.2 & 155 & 1.1 & 0.9 to 1.3 \\
\hline Cirrhosis of liver (571) & 2 & 0.9 & 0.2 to 3.6 & 12 & 0.8 & 0.5 to 1.5 & 110 & 1.1 & 0.9 to 1.3 \\
\hline Accidents (800-999) & 2 & 0.7 & 0.2 to 2.9 & 20 & 1.0 & 0.6 to 1.6 & 125 & 1.0 & 0.8 to 1.2 \\
\hline
\end{tabular}

$($ ) $=$ Number of expected deaths when observed $=0$.

Table 2 shows the mortality among males. In all zones, overall mortality did not differ from expectations. In zone $\mathrm{A}$, a borderline significantly increased mortality from circulatory and respiratory diseases was found. Mortality from chronic ischaemic heart disease was notably high, with a threefold increase; four out of five deaths occurred in the first decade after the accident (RR 3.5; 95\% CI 1.3 to 9.3). Mortality from cerebrovascular disease was only slightly, non-significantly increased, and the increased risk was confined to the first decade after the accident (five deaths; RR 2.2; 95\% CI 0.9 to 5.4). The excess mortality from respiratory disease, mainly chronic obstructive pulmonary diseases, had an RR approaching 4.0. The risk was higher in the first five years after the accident, with three deaths and RR 7.1 (95\% CI 2.3 to 22.4). Mortality from digestive disease and accidents did not depart from expectations. In zone $\mathrm{B}$, diabetes, chronic ischaemic heart disease, and cerebrovascular disease showed a $20 \%-30 \%$ non-significant excess. Deaths due to myocardial infarction were fewer than expected. In zone $\mathrm{R}$, departures from expectations were found for chronic ischaemic heart disease, and possibly for hypertension.

Table 3 shows mortality among females. Overall mortality was not increased. In zone A, significantly increased risks were found for chronic rheumatic heart disease and hypertensive vascular disease; a possibly increased mortality from diabetes, based on two deaths, was also found. In zone B, mortality from diabetes showed a significant $90 \%$ excess. Nine out of 13 deaths from diabetes occurred in the second decade after the accident giving an RR of 3.1 (95\% CI 1.6 to 6.1 ). A significantly increased risk was also found for chronic obstructive pulmonary diseases. In zone $\mathrm{R}$, mortality from hypertension was clearly increased; diabetes, chronic ischaemic heart disease, cerebrovascular disease, and chronic obstructive lung disease showed slightly increased risks of borderline significance.

\section{Discussion}

In the 15 year period after the Seveso accident, increased deaths from cardiovascular disease, chronic obstructive pulmonary disease, and diabetes were found in the population residing at the time of the accident in the area contaminated by TCDD.

The cardiovascular mortality was most prominently increased in the area of highest exposure and among males. Chronic ischaemic heart disease, in particular, was significantly increased in zone A (with most of the deaths occurring within 10 years), and increased, although to a lesser extent, in zones B and R. Among females, no overall increase in cardio-

Table 3 Mortality, 1976-91, from non-malignant causes in the Seveso population (females, all ages)

\begin{tabular}{|c|c|c|c|c|c|c|c|c|c|}
\hline \multirow{2}{*}{$\begin{array}{l}\text { Cause of death } \\
\text { ICD-9 }\end{array}$} & \multicolumn{3}{|l|}{ Zone $A$} & \multicolumn{3}{|l|}{ Zone B } & \multicolumn{3}{|l|}{ Zone $R$} \\
\hline & $\begin{array}{l}\text { Observed } \\
\text { deaths }\end{array}$ & $\begin{array}{l}\text { Relative } \\
\text { risk }\end{array}$ & $95 \% C I$ & $\begin{array}{l}\text { Observed } \\
\text { deaths }\end{array}$ & $\begin{array}{l}\text { Relative } \\
\text { risk }\end{array}$ & $95 \% C I$ & $\begin{array}{l}\text { Observed } \\
\text { deaths }\end{array}$ & $\begin{array}{l}\text { Relative } \\
\text { risk }\end{array}$ & $95 \% C I$ \\
\hline All causes (1-999) & 30 & 1.0 & 0.7 to 1.5 & 176 & 1.0 & 0.8 to 1.1 & 1589 & 1.0 & 1.0 to 1.1 \\
\hline Infectious, parasitic disease (1-139) & $(0.1)$ & & & $(0.5)$ & & & 4 & 1.1 & 0.4 to 3.1 \\
\hline Diabetes $(250)$ & 2 & 1.8 & 0.4 to 7.3 & 13 & 1.9 & 1.1 to 3.2 & 74 & 1.2 & 1.0 to 1.6 \\
\hline All circulatory disease $(390-459)$ & 12 & 1.0 & 0.6 to 1.7 & 74 & 1.0 & 0.8 to 1.2 & 759 & 1.1 & 1.0 to 1.2 \\
\hline Chronic rheumatic heart disease $(390-398)$ & 3 & 15.8 & 4.9 to 50.4 & $(1.2)$ & & & 11 & 1.2 & 0.6 to 2.3 \\
\hline Hypertension (400-405) & 3 & 3.6 & 1.2 to 11.4 & 3 & 0.6 & 0.2 to 1.8 & 72 & 1.6 & 1.2 to 2.0 \\
\hline Ischaemic heart disease (410-414) & 1 & 0.3 & 0.0 to 2.0 & 24 & 1.1 & 0.7 to 1.6 & 210 & 1.0 & 0.9 to 1.2 \\
\hline Myocardial infarction (410) & 1 & 0.6 & 0.1 to 4.0 & 9 & 0.8 & 0.4 to 1.6 & 77 & 0.8 & 0.6 to 1.0 \\
\hline Chronic ischaemic heart disease $(412,414)$ & $(1.9)$ & & & 15 & 1.3 & 0.8 to 2.2 & 133 & 1.3 & 1.0 to 1.5 \\
\hline Cerebrovascular disease $(430-438)$ & 2 & 0.5 & 0.1 to 2.0 & 26 & 1.0 & 0.7 to 1.5 & 258 & 1.2 & 1.0 to 1.3 \\
\hline Respiratory disease $(460-519)$ & 2 & 1.3 & 0.3 to 5.3 & 8 & 0.9 & 0.4 to 1.7 & 71 & 0.8 & 0.7 to 1.1 \\
\hline \multicolumn{10}{|l|}{ Chronic obstructive pulmonary disease } \\
\hline$(490-493)$ & 1 & 2.1 & 0.3 to 14.9 & 7 & 2.4 & 1.1 to 5.1 & 34 & 1.3 & 0.9 to 1.9 \\
\hline Digestive disease (520-579) & 2 & 1.2 & 0.3 to 5.0 & 13 & 1.3 & 0.8 to 2.3 & 88 & 1.1 & 0.9 to 1.4 \\
\hline Cirrhosis of liver (571) & $(0.9)$ & & & 4 & 0.7 & 0.3 to 1.9 & 46 & 1.0 & 0.8 to 1.4 \\
\hline Accidents (800-999) & 2 & 1.5 & 0.4 to 6.0 & 7 & 0.8 & 0.4 to 1.8 & 69 & 1.0 & 0.8 to 1.4 \\
\hline
\end{tabular}

( ) $=$ Number of expected deaths when observed $=0$. 
vascular mortality was found. Deaths from chronic rheumatic heart disease and hypertension, although few in number, showed a remarkable excess in zone $A$ and a lower increase in zone $\mathrm{R}$, whereas chronic ischaemic heart disease was slightly in excess in zones $\mathrm{B}$ and $\mathrm{R}$.

The excessive mortality from respiratory disease among males was clearly confined to zone A and was due to chronic obstructive pulmonary disease. Mortality from this disease was also increased among females, particularly in zones $\mathrm{A}$ and $\mathrm{B}$.

Mortality from diabetes was increased among females in all zones, and significantly so in zone B. Among males, no deaths from diabetes were found in zone $\mathrm{A}$, and the increase in other zones was only suggestive.

The varying population size in different zones had a major influence on the power of the study to detect unusual relative risks. The small number of deaths in some of the subcohorts (especially in zone A and in subcohorts obtained after stratification by-for example, duration of exposure or latency) still limits interpretation of the results.

Exposure definition solely based on levels of soil contamination is another limitation. However, results of measurements of TCDD in blood, although limited, ${ }^{49}$ support the plausibility of the adopted exposure classification. Inhabitants of zone $\mathrm{A}$ had the highest exposure; this was able to be documented because of the long half life of TCDD, and could be shown many years after they had left the area. In zone B, exposure was high and people living in the area might have been accumulating high doses over time. Biological data also confirmed that in zone $\mathrm{R}$, the least contaminated zone, exposure was low, but definitely higher than background levels. Measured concentrations in a sample of the reference population were, as expected, ${ }^{39}$ very close to the estimated background levels in industrial countries. ${ }^{42}$

The comparability of the relevant features of the exposed and reference populations was verified on the basis of the census data and not by comparing individual people's characteristics. Despite this limitation, differences in health determinants - such as those necessary to explain the noted differential mortality from certain causes - would hardly have gone undetected.

The increased risk of cardiovascular disease in the exposed population was from chronic ischaemic heart disease, chronic rheumatic heart disease, and hypertension.

The effects of TCDD on the cardiovascular system have been examined in several animal species, showing that TCDD can alter cardiac function and morphology. Reported effects include functional disturbances, ${ }^{43-46}$ preatherosclerotic lesions in the aorta, ${ }^{45}$ myocardial degeneration, ${ }^{47}$ ventricular dilatation, and myocardial hypertrophy. ${ }^{48}$ Experimental data also showed that TCDD causes increased serum triglycerides and cholesterol, ${ }^{49-51}$ well known risk factors for cardiovascular diseases. ${ }^{52}$

Epidemiological studies in human populations yielded inconsistent findings. Cross sec- tional medical studies could not detect differences between exposed and non-exposed workers. ${ }^{18} 5354$ Participation bias and lack of clinically verified diagnoses affect the validity of these results. The largest occupational mortality studies in workers exposed to chlorophenoxy herbicides or chlorophenols contaminated with TCDD, either in Europe or in the United States, did not detect an increased risk of cardiovascular diseases. ${ }^{55}$ The main focus of these studies was, however, on cancer mortality; analysis by specific categories of cardiovascular deaths was not reported; and detailed evaluation of exposure relative to cardiovascular outcomes was lacking. Moreover, the RR estimates were around 1.00, whereas when the mortality of an occupational cohort is compared with that of the general population, a deficit of cardiovascular mortality is usually found. ${ }^{57}$ The absence of the so called "healthy worker effect" might actually suggest that even in those industrial cohorts exposed to TCDD an increased cardiovascular mortality existed. Three occupational studies were able to investigate mortality from ischaemic heart disease relative to estimated individual TCDD doses. One did not detect an effect of TCDD on mortality from ischaemic heart disease, ${ }^{58}$ whereas two showed a positive relation: mortality from ischaemic heart disease increased with increasing TCDD concentrations. ${ }^{27} 28$

Mortality and morbidity due to circulatory disease have been examined also among Vietnam veterans. The results of the various studies are not consistent. Often they refer to self reported diagnosis; in some instances control of confounders is lacking; combat experience itself has been reported as a possible causal factor; no clear dose response emerged when examined. ${ }^{59}$ Only one study reported an increased mortality from circulatory disease among "non-flying enlisted personnel", a subgroup of "ranch hands" (troops employed in the aerial spraying of "agent orange") with higher current TCDD serum concentrations than other ranch hands. ${ }^{60}$

In the Seveso population, two components of the accident experience emerge as possible explanations of the excesses found: the chemical exposure and the disaster experience with its burden of psychosocial stressors. For chronic ischaemic heart disease, the role of accident stressors was most probable in exacerbating already existing ill health. This hypothesis would be consistent with the highest risks detected in zone $\mathrm{A}$, where subjects experienced the greatest psychosocial impact of the accident - for example, many had to leave their houses and family run shops-social support was thought to be insufficient and the experience of rejection was common; great uncertainty was experienced about the future, including health of children and future generations. ${ }^{6162}$ The hypothesis would also be consistent with the early occurrence of excess deaths after the accident and with the prevailing type (chronic) of cardiovascular disorders. The role of TCDD exposure as a possible risk factor is consistent with the zone A population being 
the most severely affected, and is supported by experimental and epidemiological data. The increased mortality from hypertension might be explained by these same risk factors. The increase of rheumatic heart disease might instead be related, at least by way of hypothesis, to the immunotoxic properties of TCDD. This, however, was one of the few causes of death for which the reference population was found to be probably underestimated. ${ }^{37}$

The excess mortality from respiratory diseases was mainly from chronic obstructive pulmonary disease (COPD), mainly in zone A males and zone $\mathrm{B}$ females. No clear relation with time since first exposure emerged among females; whereas the excess found among zone A males was mainly detected in the first five years after the accident, and mainly affected elderly men. One reasonable hypothesis is that the same accident related factors discussed for cardiovascular deaths could have precipitated early deaths among people with pre-existing chronic respiratory disease. Another possible explanation rests with a differential death certification in exposed and non-exposed areas, given the higher than usual proportion of COPD where an excess of deaths related to the respiratory system was found; this explanation seems less probable because there was a common certifying physician, and because COPD was not considered to be an illness related to TCDD. Coding, on the other hand, was performed by the same person unaware of the exposure status of the subjects. Previous cohort and cross sectional studies in humans do not support an association between TCDD exposure and non-malignant respiratory disorders. ${ }^{63}$ The immunotoxic action of TCDD might be a relevant and plausible explanatory factor: impaired protection and defence against episodes of respiratory infection play a major part in the natural history of chronic obstructive pulmonary disease. ${ }^{64}$

Smoking is supposed to be considered as the main confounding factor for the increase of both cardiovascular and respiratory diseases. All the available evidence is, however, against this explanation, including the absence of increased risks from respiratory and other cancers associated with smoking ${ }^{65}$; the similar social, cultural, and occupational characteristics (all variables possibly related to personal habits) of the index and control population; the highest relative risks in the most exposed subgroups; and the extremely large differences in smoking habits needed to explain confounding relative risks as high as those found. ${ }^{66}$

Diabetes mellitus was increased in zones A and $\mathrm{B}$ among females. The risk was particularly high in the second decade after the accident. Recent investigations in male populations exposed to dioxin support a positive association between TCDD serum concentrations and diabetes and fasting serum glucose concentrations. ${ }^{216768}$ In Seveso, however, only women were affected. This finding might be explained by the complex, and not fully understood, interaction of dioxin with hormonal factors, ${ }^{69}$ or the systematically higher TCDD concentrations in females than in males. ${ }^{39}$ It was unlikely that diet played any part. On the contrary, diet is one of the main characteristics by which the area including the exposed and reference territory is identified as a particular regional entity.

In conclusion, the study of non-malignant health effects in this population accidentally exposed to substantial amounts of relatively pure TCDD uncovered an increased mortality from cardiovascular and respiratory diseases and from diabetes, which could not be explained solely by chance, bias, or confounding. Although no definite conclusion can be drawn at this stage, the association of the increased risks with exposure to TCDD seems possible and plausible.

1 Dickson LC, Buzik BSP. Health risks of dioxins: a review of environmental and toxicological considerations. Vet Hum Toxicol 1993;35:68-77.

2 Vanden Heuvel JP, Lucier G. Environmental toxicology of polychlorinated dibenzo-p-dioxins and polychlorinated dibenzofurans. Environ Health Perspect 1993;100:189-200.

3 De Vito MJ, Birnbaum LS. Toxicology of dioxins and related chemicals . In: Schecter A, ed. Dioxins and health. New York: Plenum Press; 1994:139-62.

4 International Agency for Research on Cancer. Monographs on the evaluation of carcinogenic risks to humans. Vol 69. Polichlorinated dibenzo-para dioxins and polichlorinated dibenzofurans. Lyon: IARC, 1997.

5 Institute of Medicine, Committee to Review the Health Effects in Vietnam Veterans of Exposure to Herbicides. Cancer. In: Veterans and agent orange: health effects of herbicides used in Vietnam. Washington: National Academy Press, 1994:433-590.

6 Poland AP, Smith D, Metter G, et al. A health survey of workers in a 2,4-D and 2,4,5-T plant with special attention to chloracne, porphyria cutanea tarda, and psychologic to chloracne, porphyria cutanea tarda, and psycho

7 Goldman PJ. Critically acute chloracne caused by trichlorophenol decomposition products. Arbeitsmed Sozialmed Arbeitshyg 1972;7:12-8.

8 Jirasek L, Kalensky J, Kubec K, et al. Acne chlorina, porphyria cutanea tarda and other manifestations of general intoxication during the manufacture of herbicides. II. Ceskoslovenska Dermatologic 1974;49:145-57.

9 Caramaschi F, Del Corno G, Favaretti C, et al. Chloracne following environmental contamination by TCDD in Seveso, Italy. Int $\mathcal{F}$ Epidemiol 1981;10:135-43.

10 Mocarelli P, Marocchi A, Brambilla P, et al. Clinical laboratory manifestations of exposure to dioxin in children. A six year study of the effects of an environmental disaster near Seveso, Italy. $\mathcal{F A M A}$ 1986;256:2687-95.

11 Beck H, Eckart K, Mathar W, et al. Levels of PCDDs and PCDFs in adipose tissue of occupationally exposed workers. Chemosphere 1989;18:507-16.

12 Bond GG, Mc Laren EA, Brenner FE, et al. Incidence of chloracne among chemical workers potentially exposed to chloracne among chemical workers potentially expo
chlorinated dioxins. F Occup Med 1989;31:771-4.

13 Zober A, Messerer P, Huber P. Thirty-four-year mortality follow up of BASF employees exposed to $2,3,7,8,-$ TCDD follow up of BASF employees exposed to 2,3,7,8,-TCDD after the 1953 accic
$1990 ; 62: 139-57$.

14 Ott MG, Zober A, Germann C. Laboratory results for selected target organs in 138 individuals occupationally exposed to TCDD. Chemosphere 1994;29:2423-37.

15 May G. Tetrachlorodibenzodioxin: a survey of subjects 10 years after exposure. Br F Ind Med 1982;39:128-35.

16 Martin JV. Lipid abnormalities in workers exposed to dioxin. Br F Ind Med 1984; 41:254-6.

17 Doss M, Sauer H, Von Tieperman R, et al. Development of chronic hepatic porphyria (porphyria cutanea tarda) with inherited uroporphyrinogen decarboxylase deficiency under exposure to dioxin. Int $\mathcal{F}$ Biochem 1984;16:369-73.

18 Moses M, Lilis R, Crow KD, et al. Health status of workers with past exposure to 2,3,7,8-tetrachlorodibenzo-p-dioxin in the manifacture of 2,4,5-thrichlorophenoxyacetic acid: comparison of findings with and without chloracne. Am $\mathcal{F}$ Ind Med 1984;5:161-82

19 Ideo G, Bellati G, Bellobuono A, et al. Urinary D-glucaric acid excretion in the Seveso area, polluted by tetrachlorodibenzo-p-dioxin (TCDD): five years of experience. Environ Health Perspect 1985;60:151-7.

20 Calvert GM, Hornung RW, Sweeney MH, et al. Hepatic and gastrointestinal effects in an occupational cohort exposed to $2,3,7,8$-tetrachlorodibenzo-para-dioxin. $\mathcal{F} A M A$ 1992; 267:2209-14

21 Roegner RH, Grubbs WD, Lustik MB, et al. Air Force health study: an epidemiologic investigation of health effects in Air Force personnel following exposure to herbicides. Serum dioxin analysis of 1987 examination results. Washington DC: analysis of 1987 examination results. Washington DC: 516 through AD A-237-524.)

22 Pluim HJ, de Vijlder JJM, Olie K, et al. Effects of pre- and postnatal exposure to chlorinated dioxins and furans on 
human neonatal thyroid hormone concentrations. Environ Health Perspect 1993;101:504-8.

23 Koopman-Esseboom C, Morse DC, Weisglas-Kuperus N, et al. Effects of dioxins and polychlorinated biphenyls on thyroid hormone status of pregnant women and their infants. Pediatr Res 1994;36:468-73.

24 Tonn T, Esser C, Schneider EM, et al. Persistence of decreased T-helper cell function in industrial workers 20 years after exposure to 2,3,7,8-tetrachlorodibenzo-pdioxin. Environ Health Perspect 1996;104:422-6.

25 Calvert GM, Willie KK, Sweeney MH, et al. Evaluation of serum lipid concentrations among US workers exposed to 2,3,7,8-tetrachlorodibenzo-p-dioxin. Arch Environ Health 1996;51:100-7

26 Wolfe WH, Michalek JE, Miner JC. Diabetes versus dioxin body burden in veterans of operation ranch hand. Organohalogen Compounds 1992;10:279-82.

27 Flesch-Janys D, Berger J, Gurn P, et al. Exposure to polychlorinated dioxins and furans $(\mathrm{PCDD} / \mathrm{F})$ and polychlorinated dioxins and furans (PCDD/F) and producing plant in Hamburg, Federal Republic of Gerproducing plant in Hamburg, Federal Rep

28 Hooiveld M, Heederick D, Bueno de Mesquita B. Preliminary results of the second follow-up of a Dutch
cohort of workers occupationaly exposed to phenoxy cohort of workers occupationaly exposed to phenoxy gen Compounds 1996;30:185-9.

29 Sweeney A. Reproductive epidemiology of dioxins. In Schecter A, ed. Dioxins and health. New York: Plenum Press; 1994:549-85

30 di Domenico A, Silano V, Viviano G, et al. Accidental release of 2,3,7,8-tetrachlorodibenzo-p-dioxin (TCDD) at Seveso, Italy. II. TCDD distribution in the soil surface layer. Ecotoxicol Environ Saf 1980;4:298-320.

31 McConnel EE, Moore JA. Toxicopathology characteristics of the halogenated aromatics. Ann N Y Acad Sci 1979;320: 138-50.

32 Bertazzi PA, Pesatori AC, Zocchetti C. The Seveso accident. In: Elliott P, Kuzick J, English D, Stern R, eds. Geographical and environmental epidemiology: methods for small area

33 Bertazzi PA, di Domenico A. Chemical, environmental, and health aspects of the Seveso, Italy, accident. In: Schecter A ed. Dioxins and health. New York: Plenum Press, 1994:587632 .

34 Bruzzi P. Health impact of the accidental release of TCDD at Seveso. In: Coulston F, Pocchiari F, eds. Accidental exposure to dioxins: human health aspects. New York: Academic Press, 1983:215-25.

35 Special Office for Seveso, International Steering Committee. Minutes of the sixth meeting of the International Steering Committee, February 19-21, 1984. Final report and recommendations, Milan: Regione Lombardia, 1984:1-17.

36 Bertazzi PA, Pesatori AC, Consonni D, et al. Cancer incidence in a population accidentally exposed to $2,3,7,8-$
tetrachlorodibenzo-para-dioxin. Epidemiology 1993;4:398406.

37 Bertazzi PA, Zocchetti C, Pesatori AC, et al. Ten-year mortality study of the population involved in the Seveso mortality study of the population involved in the Seves

38 Istituto Centrale di Statistica. XII Population census, October 25,1981 . Data on population structure and housing characteristics. Vol II Tome I Provincial dossier n.15- Milano. Roma, ISTAT, 1984.

39 Landi MT, Needham LL, Lucier G, et al. Concentrations of dioxin 20 years after Seveso. Lancet 1997;349:1811.

40 Bertazzi PA, Zocchetti C, Pesatori AC, et al. Mortality in an area contaminated by TCDD following an industrial accident. Med Lav 1989;80:316-29.

41 Breslow NE, Day NE. Statistical methods in cancer research. Vol II. The design and analysis of cohort studies. Lyon: International Agency for Research on Cancer, 1987. (IARC Sci Publ No 82.)

42 Schecter AJ, Päpke O, Ball $\mathrm{M}$, et al. Dioxin and dibenzofuran levels in human blood samples from Guam, Russia, Germany, Vietnam, and the USA. Chemosphere 1992;25:1129-34.

43 Kelling CK, Menahan LA, Peterson RE. Effects of 2,3,7,8tetrachlorodibenzo-p-dioxin treatment on mechanical
function of the rat heart. Toxicol Appl Pharmacol 1987;91: function

44 Hermansky SJ, Holcslaw TL, Murray WJ, et al. Biochemical and functional effects of 2,3,7,8-tetrachlorodibenzo-pdioxin (TCDD) on the heart of female rats. Toxicol App Pharmacol 1988;95:175-84.

45 Brewster DW, Bombick DW, Matsumura F. Rabbit serum hypertriglyceridemia after administration of 2,3,7,8tetrachlorodibenzo-p-dioxin (TCDD). 7 Toxicol Environ Health 1988;25:495-507.

46 Canga L, Levi R, Rifkind AB. Heart as a target organ in 2,3,7,8-tetrachlorodibenzo-p-dioxin toxicity: decreased $\beta$ adrenergic responsiveness and evidence of increased intracellular calcium. Proc Natl Acad Sci USA 1988;85: 905-9.

47 Kociba RJ, Keyes DG, Beyer JE, et al. Results of a two-year chronic toxicity study and oncogenicity study of $2,3,7,8-$ tetrachlorodibenzo-p-dioxin in rats. Toxicol Appl Pharmacol 1978;46:279-303.

48 Allen JR, Barsotti DA, Van Miller JP, et al. Morphological changes in monkeys consuming a diet containing low levels of 2,3,7,8-tetrachlorodibenzo-p-dioxin. Food Cosmet Toxicol 1977;15:401-10.

49 Gasiewicz TA, Neal RA. 2,3,7,8-tetrachlorodibenzo-pdioxin tissue distribution, excretion, and effects on clinical chemical parameters in guinea pigs. Toxicol Appl Pharmacol 1979;51:329-39.

50 Brewster DW, Matsumura F. TCDD (2,3,7,8tetrachlorodibenzo-p-dioxin) reduces lipoprotein lipase activity in the adipose tissue of the guinea pig. Biochem Biophys Res Commun 1984;122:810-7.

51 Lovati MR, Galbussera M, Franceschini G, et al. Increased plasma and aortic triglycerides in rabbits after acute administration of 2,3,7,8-tetrachlorodibenzo-p-dioxin . Toxicol Appl Pharmacol 1984;75:91-7.

52 Castelli WP. Lipids, risk factors, and ischaemic heart disease. Atherosclerosis 1996;(suppl):S1-9.

53 Bond GG, Ott MG, Brenner FE, et. Medical and morbidity surveillance findings among employees potentially exposed to TCDD. Br f Ind Med 1983;40:318-24.

54 Suskind RR, Hertzberg VS. Human health effects of 2,4,5-T and its toxic contaminants. FAMA 1984;251: $2372-80$.

55 Saracci R, Kogevinas M, Bertazzi PA, et al. Cancer mortality in workers exposed to chlorophenoxy herbicides and chlorophenols. Lancet 1991;338:1927-32.

56 Fingerhut MA, Halperin WE, Marlow DA, et al. Cancer mortality in workers exposed to $2,3,7,8$-tetrachlorodibenzop-dioxin. N Engl f Med 1991;324:212-8.

57 Fox AJ, Collier PF. Low mortality rates in industrial cohort studies due to selection for work and survival in the industry. Br F Prev Soc 1976;30:225-30.

58 Ott MG, Zober A. Cause specific mortality and cancer incidence among employees exposed to 2,3,7,8-TCDD after a 1953 reactor accident. Occup Environ Med 1996;53:60612.

59 Institute of Medicine, Committee to Review the Health Effects In Vietnam Veterans of Exposure to Herbicides. In: Veterans and agent orange: health effects of herbicides used in Vietnam. Washington: National Academy Press, 1994:699708.

60 Air Force Health Study. An epidemiologic investigation of health effects in Air Force personnel following exposure to herbicides. Serum dioxin analysis of 1987 examination results. Brooks AFB, TX: USAF School of Aerospace Medicine, 1991:9.

61 Pesatori AC. Dioxin contamination in Seveso: the social tragedy and the scientific challenge. Med Lav 1995;86:11124

62 Bertazzi PA. Industrial disasters and epidemiology. A review of recent experiences. Scand $\mathcal{F}$ Work Environ Health $1989 ; 15: 85-100$

63 Institute of Medicine, Committee to Review the Health Effects In Vietnam Veterans of Exposure to Herbicides. In: Veterans and agent orange: health effects of herbicides used in Vietnam. Washington: National Academy Press, 1994:70814.

64 Speizer FE, Tager IB. Epidemiology of chronic mucus hypersecretion and obstructive airway disease. Epidemiol Rev 1979;1:124-42.

65 Bertazzi PA, Zocchetti C, Guercilena S, et al. Dioxin exposure and cancer risk. A 15-year mortality study after the Seveso accident. Epidemiology 1997;8

66 Axelson A, Steenland K. Indirect methods of assessing the effects of tobacco use in occupationale studies. $A m \mathcal{F}$ Ind Med 1988;13:105-18.

67 Pazderova-Vejlupkova J, Lukas E, Nemcova M, et al. The development and prognosis of chronic intoxication by tetrachlorodibenzo-p-dioxin in men. Arch Environ Health 1981;36:5-11

68 Sweeney MH, Hornung RW, Wall DK, Fingerhut MA, Halperin WE. Prevalence of diabetes and increased fasting serum glucose in workers with long-term exposure to 2,3,7,8-tetrachlorodibenzo-p-dioxin. Organohalogen Compounds 1992;10:225-6.

69 Lucier GW, Tritscher A, Goldsworthy T, et al. Ovarian hormones enhance 2,3,7,8-tetrachlorodibenzo-p-dioxin mediated increases in cell proliferation and preneoplastic foci in a two-stage model for rat hepatocarcinogenesis. Cancer Res 1991;51:1391-7. 